\title{
Groundnut Rust (Puccinia arachidis) Management through Integration of Host Resistance with Fungicides at Babile,
}

\section{Eastern Ethiopia}

\author{
Alehegn $\mathrm{M}^{1}{ }^{*}$, Sakhuja $\mathrm{PK}^{2}$ and Dejene $\mathrm{M}^{2}$ \\ ${ }^{1}$ Department of Horticulture, Debre Markos University, Ethiopia \\ ${ }^{2}$ School of Plant Sciences, Haramaya University, Ethiopia
}

*Corresponding author: Alehegn M, Department of Horticulture, Debre Markos

\section{Research Article \\ Volume 2 Issue 2}

Received Date: February 03, 2017

Published Date: February 21, 2017 University, Ethiopia, Fax: - 0587711764; Phone:-0587716769, E-mail: mastewal.alehegn@gmail.com

\section{Abstract}

The field experiment was carried out at Babile Research Sub-Station of Haramaya University in 2010 main cropping season to evaluate the efficacy of four fungicides (chlorothalonil a rate of $0.2 \mathrm{~kg}^{-\mathrm{ha}} \mathrm{-}^{-1}$, copper hydroxide at a rate of $2.3 \mathrm{~kg}$ $\mathrm{ha}^{-1}$, mancozeb at a rate of $0.25 \mathrm{~kg}^{-\mathrm{ha}^{-1}}$ and triadimefon at a rate of $0.5 \mathrm{~kg}-\mathrm{ha}^{-1}$ ) on groundnut rust (Puccinia arachidis) development and grain yield. The experiment was laid out in a randomized complete block design (RCBD) in factorial arrangement with three replications. Two groundnut varieties were used for the experiment namely, Shulamith (susceptible) and Sedi (moderately resistance). The fungicide treatments resulted in different levels of disease severity on the two groundnut varieties used [i.e. Shulamith (susceptible) and Sedi (moderately resistant) varieties]. Plots sprayed with triadimefon had significantly ( $p \leq 0.001$ ) lower level (257.37\%-days) of AUDPC of groundnut rust than plots treated with other fungicides. Three times spray with triadimefon at a rate of 0.5 a.i. kg-ha-1 at 15 -day-interval proved to be the best groundnut rust management system giving the lowest disease parameters and highest yield 1644.44 kg-ha-1. Four times spray with mancozeb at a rate of 0.25 a.i. kg-ha-1 at 10 -day interval proved to be the second best fungicide in significantly reducing the disease. Percentage severity indexes (PSI), area under disease progress curve (AUDPC) and disease progress rate were negatively correlated with groundnut seed yield. The highest rust severity $67.65 \%$ and lowest yield 1014.60 kg-ha-1 were recorded on the unsprayed control shulamith plots. On Shulamith variety, rust severity of up to $67.65 \%$ and relative yield loss of $35.55 \%$ were recorded in unsprayed plots. Generally, the current research results indicate that effective management of groundnut rust and significant yield benefit can be obtained when triadimefon fungicide spray is started just before or at the onset of the disease and properly continued at 15-day interval

Keywords: Arachis hypogaea; AUDPC; Fungicide; Incidence; Puccinia arachidis; Severity; Spray schedule

\section{Introduction}

Groundnut (Arachis hypogaea L.) is an important oilseed crop, grown throughout the tropical and subtropical regions between $40^{\circ} \mathrm{S}$ and $40^{\circ} \mathrm{N}$ of the equator and where the annual rainfall ranges from 500 to 1200 $\mathrm{mm}$ with an average daily temperature of higher than $20^{\circ} \mathrm{C}$. It is grown in over 100 countries in six continents, mainly in Africa, America and Asia, with a world 


\section{Open Access Journal of Agricultural Research}

production of 37.1 million metric tons with cultivation area of 23.11 million hectares [1]. Groundnut is one of the four economically important oilseed crops in Ethiopia that include flax, noug and sesame and is largely produced in the eastern parts of the country [2]. Groundnut plays an important role in the diets of rural populations, particularly children, because of its high protein (21$30 \%$ ), fat (41-52\%), and carbohydrate (11-27\%) contents [3]. It is also rich in calcium, magnesium, phosphorus, potassium, nicotinic acid, vitamin $\mathrm{B}_{1}, \mathrm{~B}_{2}, \mathrm{~B}_{6}$, vitamin $\mathrm{E}$ and other vitamins. It is also a good source of lecithin present in the range between 0.5 and $0.7 \%$ in decorticated nuts. Groundnut butter has become a common and popular edible diet. Groundnut cake has high nutritive value for human consumption. The groundnut flour is suitable for supplementing white flour groundnuts. Generally, the use of groundnut is diverse: all parts of the plant can be used; the nut (kernel) is rich source of edible oil where about two-third of the world production is crushed for oil extraction [4]. In eastern Ethiopia, mainly high quality edible oil is extracted from groundnut and cakes are made from the remaining residue.

The groundnut shell is used for fuel and as organic fertilizer in many regions. The haulms are nutritious and widely used for feeding livestock. Besides its superior food value, groundnut also provides a source of cash for resource-poor farmers. Groundnut earns foreign currency for Ethiopia where over 2 million US dollars was obtained in 1989 crop season alone [5]. With the current interest in export-oriented agriculture, the future groundnut market situation appears attractive and profitably promising for Ethiopia. Despite its importance, the average national yield (about $1.2 \mathrm{t}^{\mathrm{t}} \mathrm{ha}^{-1}$ ) of groundnut in Ethiopia is significantly lower than is potentially achievable (over 2.0 $\mathrm{t}$-ha $\left.{ }^{-1}\right)$ [6]. This large gap between actual and potential yields is due to several factors, including unavailability of seeds of improved varieties, poor soil fertility, inappropriate crop management practices, and insect pests and diseases. Soil-borne fungal diseases like charcoal rot (Macrophomin aphaseoli), pod rot (Pythium spp.), stem rot (Sclerotium rolfsii) and root rot (Rhizoctoniasolani) as well as foliar diseases are the major constraints that decrease the productivity of the crop in eastern Hararghe [7]. The major foliar diseases of groundnut caused by fungi include rust (Puccinia arachidis Speg.), late leaf spot (Cercosporapersonata (Berk \& Curt) Ell \& Eve and early leaf spot (Cercospora arachidicola Hori). Groundnut rust and late leaf spots are important diseases in India and most of the Semi-Arid Tropic (SAT) regions [8]. Foliage fungal diseases, especially leaf rust and Cercospora leaf spots result in severe yield losses in groundnut production areas of Ethiopia. Leaf rust causes yield reduction reaching up to $65 \%$, especially in areas with high rainfall [6]. Rust occurs regularly in several countries along with late leaf spot, mainly in low altitude areas [9]. Uredospores could be stored for a long period at low temperature without loss of their viability when stored in the range of 25 to $30^{\circ} \mathrm{C}$, the optimum for uredospore germination. The uredospores are short-lived and any break between crop seasons would be unfavorable for their carry over [10].

Babile, Gursum, Fedis and Harar are traditional groundnut growing-areas or districts on large scale in eastern Ethiopia. Rust occurs every year in many parts of eastern Ethiopia and causes yield losses in food insecure areas affecting the livelihood of farmers [7]. To reduce its prolific development and growth, cultural practices have par amount advantage, for instance, time of planting, addition of fertilizer and intercropping have critically reduced rust development and survival rate. Foliar applications of fungicides have been reported to markedly reduce rust development [11]. To this effect, it is important to seek out suitable solution to the groundnut rust problems through fungicide applications. Therefore, this study was designed and carried out with the specific objective to evaluate the effect of fungicide sprays on groundnut rust development and yield.

\section{Materials and Methods}

\section{Description of the Study Site}

The field experiment was conducted at Babile Research Sub-Station of Haramaya University located at $555 \mathrm{~km}$ from Addis Ababa in East Hararghe Zone in 2010 main cropping season. The Research Station is located at $9^{\circ} 08^{\prime} 40^{\prime \prime} \mathrm{N}$ latitude and $42^{\circ} 21^{\prime} 30^{\prime \prime} \mathrm{E}$ longitude at an altitude of $1650 \mathrm{~m}$ a.s.l. The area is characterized by bimodal rainfall pattern occurring mainly during March to May and July to October, with an average annual rainfallof $671 \mathrm{~mm}$ and a mean temperature of $22{ }^{\circ} \mathrm{C}$. The averaged annual temperature data for Babile shows a maximum and a minimum temperature of $28.05{ }^{\circ} \mathrm{C}$ and $15.52{ }^{\circ} \mathrm{C}$, respectively. The type of soil at Babile Research SubStation is a well drained sandy-loam with $\mathrm{pH} 7.0$, organic matter $1.9 \%$ and available phosphorus $3.2 \mathrm{ppm}$ [12]. 


\section{Open Access Journal of Agricultural Research}

\section{Evaluation of Effects of Fungicides on Groundnut Rust and Yield}

The experiment was conducted to evaluate the efficacy of four foliar fungicides to manage groundnut rust at Babile Research Sub-Station of Haramaya University during 2010 main cropping season.

Treatments, experimental procedures and design: A 2 $\times 5$ factorial combination of two groundnut varieties, namely Shulamith (susceptible) and Sedi (moderately resistant) and four fungicides (chlorothalonil at a rate of 0.2 a.i. kg-ha- ${ }^{-1}$, copperhydroxide at a rate of 2.3 a.i. kg-ha- ${ }^{-1}$, mancozeb at a rate of 0.25 a.i. kg-ha-1 ${ }^{-1}$ and triadimefon at a rate of 0.5 a.i. $\mathrm{kg}^{-h^{-1}}$ ) along with non-treated controls were arranged in a randomized complete block design (RCBD) with three replications. Three of the four fungicides were contact type and one was systemic type. The plot size was $5 \mathrm{~m} \times 2 \mathrm{~m}$ (i.e. $10 \mathrm{~m}^{2}$ ) and there were five rows per plot, and five plants per row were taken from the central three rows, hence 15 plants per plot were tagged for data recording. The distance between plots was $60 \mathrm{~cm}$, while the distance between adjacent blocks was $1 \mathrm{~m}$ and row-to-row distance was $35 \mathrm{~cm}$ and plant-to-plant distance was $25 \mathrm{~cm}$. Planting was done on 30 April 2010 by dropping two seeds per hole and the less vigorous seedlings were thinned out later on. Weeding and all other recommended agronomic practices were done as required.

Fungicide sprays: Foliar spraying of the fungicides was started 7 days before the first disease assessment (78 days after planting, DAP), i.e. when the first symptoms of the disease appeared. Three of the four fungicides namely, chlorothalonil copperhydroxide and mancozeb were sprayed at ten day interval while the systemic fungicide i.e triadimefon was sprayed at 15 day interval. Spraying was performed by using a knapsack sprayer and plastic sheet was used as a shield during fungicide spraying to separate the plot being sprayed from the adjacent plots to prevent inter-plot interference of spray drift. Unsprayed plots were left for each groundnut variety as controls.

Disease assessment procedures: Disease incidence was recorded two times (78 and 85 DAP) based on the first appearance of the disease symptoms. Disease severity was recorded seven times at seven-day interval by visual estimation of the percentage leaf area diseased. The disease severity estimates were rated using 1-9 disease scale [13]. Disease severity scores were then converted into percentage severity index (PSI) for the analysis using the formula stated below [14].

$$
\text { PSI }=\frac{\text { SNR } \times 100}{\text { No. PS } \times \text { MSS }}
$$

Where SNR =Sum of numerical ratings, No.PS= number of plants scored and MSS= maximum score on scale.

\section{Data collected in the field}

Disease data: Disease incidence was assessed by counting the number of plants showing rust symptoms on the central three rows of every plot in proportion to the total plants in the three rows and then converted into percentage and disease severity was assessed by observing the percent tissue area affected by the disease on 15 tagged plants in the central three rows of every plot. Disease severity data were recorded using 1-9 disease scale [13]. Severity was expressed as PSI computed based on 1-9 disease scale. Then the area under disease progress curve (AUDPC) was calculated for each plot using the formula developed by Shanner and Finney (1977) [15] as follows.

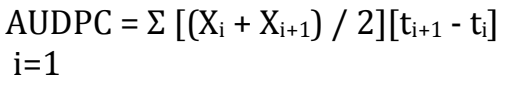

Where $\mathrm{x}_{\mathrm{i}}$ is the cumulative disease severity expressed as a proportion at the $\mathrm{i}^{\text {th }}$ observation (percentage of disease severity) $t_{i}$ is time of the $i^{\text {th }}$ assessment in days from the first assessment date and $\mathrm{n}$ is the total number of assessments made.

Agronomic data: Stand count at harvest, number of pods per plant, number of seeds per pod, hundred seed weight shelling percentage and yield in $\mathrm{kg}^{-\mathrm{ha}^{-1}}$ were recorded. Stand count at harvest was counted from the central three rows at harvest. Number of pods per plant was recorded from 15 tagged plants in the three central rows at harvest. Number of seeds per pod was recorded from the 15 tagged plants and five pods were shelled from each plant to find out the number of seeds per pod. Hundred seed weight was determined by measuring the mass of randomly picked 100 seeds from each plot using a sensitive balance. Shelling percentage was estimated as shell weight divided by dry pod weight multiplied by 100 using1 kg dry pod. Seed yield in $\mathrm{kg}^{-\mathrm{ha}^{-1}}{ }^{1}$ was estimated from the middle three rows whereby all plants in the three rows were harvested and weight of seeds recorded. The seed yield was then expressed in terms of yield per hectare for statistical analysis.

Relative yield loss was also calculated based on the following formula [16]:

$\% \mathrm{RYL}=[(\mathrm{YP}-\mathrm{Yt}) / \mathrm{YP}] \times 100$ 


\section{Open Access Journal of Agricultural Research}

Where $\% \mathrm{RYL}=$ relative percent yield loss, $\mathrm{YP}=\mathrm{yield}$ from the maximum protected plot (sprayed treatment) $\mathrm{Yt}=$ yield from plots of other treatments including unsprayed control plots.

Data analyses: The percentage data on disease incidence and severity were subjected to ANOVA to determine the treatment effects. Mean disease severity from each plot was used in data analysis. Disease progress rate was obtained from the regression of PSI data fit to logistic model loge (y/1-y) [17] with dates of assessments. Correlation analysis was performed to determine the relationship between yield and AUDPC across the treatments. The relationships of AUDPC, severity, disease progress rate and yield were examined using correlation analysis. Least significant difference (LSD) value was used to separate the treatment means. Data were analyzed by using Statistical Analysis System (SAS) Software Version 9.0.

\section{Results and Discussion}

\section{Effects of Fungicides on Groundnut Rust Development and Yield}

The effects were evaluated using the disease parameters including disease incidence, disease severity, AUDPC, disease progress rate and relative yield loss.

\section{Disease progress}

In this study, disease progress was compared among the different fungicide treatments using percent severity index (PSI), area under disease progress curve (AUDPC) and disease progress rate $(\mathrm{r})$. All these analytical methods were useful tools in quantifying disease epidemics. The disease progress rate helps to determine whether disease develops in one treatment faster than the other, while AUDPC enables to predict yield [18].

\section{Percent severity index (PSI)}

Groundnut rust severities on the varieties Shulamith and Sedi at different DAP were estimated and depicted (Figures 1 \& 2). There was significant $(\mathrm{p} \leq 0$. 05) difference between varieties on all dates of disease severity assessments. The disease severity difference between the two varieties during the first assessment might be due to random attack by the rust and the varietal genetic differences. But severity variation was clearly observed one week after application of the fungicides.

Mean PSI was higher in the susceptible variety Shulamith than the moderately resistant variety Sedi
(Figure $1 \& 2$ ).The effect of foliar spray fungicides in reducing PSI was highly and significantly ( $\mathrm{p} \leq 0.001$ ) different in all dates of assessment. Moreover, the interaction effects of foliar spray fungicides and varieties were significantly $(\mathrm{p} \leq 0.05)$ different in reducing PSI after the second assessment date and thereafter. However, the fungicides sprayed had varying effects on groundnut rust severity. Plots sprayed with triadimefon at 15-day interval showed significant suppressive effect on the severity of groundnut rust on both varieties. But, none of the fungicide treatments completely controlled the development of the disease (Figure $1 \& 2$ ). On the other hand, spraying triadimefon at 15-day interval and mancozeb at 10-day interval significantly reduced disease severity as compared to chlorothalonil, copperhydroxide and the unsprayed plot (Figure $1 \& 2$ ).

Generally, the disease progress curves (Figure $1 \& 2$ ) showed higher disease progress in the two varieties (Shulamith and Sedi) on unsprayed plots and then the degree of disease severity decreased downward and the effectiveness of the fungicides was concurrently increased (Figure 1 \& 2). According to Singh et al. (1981) [19] triadimefon gave good control of rust on French bean in India, where it reduced the severity of French bean rust by $55 \%$. The investigators also reported that application of triadimefon reduced groundnut rust intensity by about $36 \%$. The present study was also comparable to the previous works.

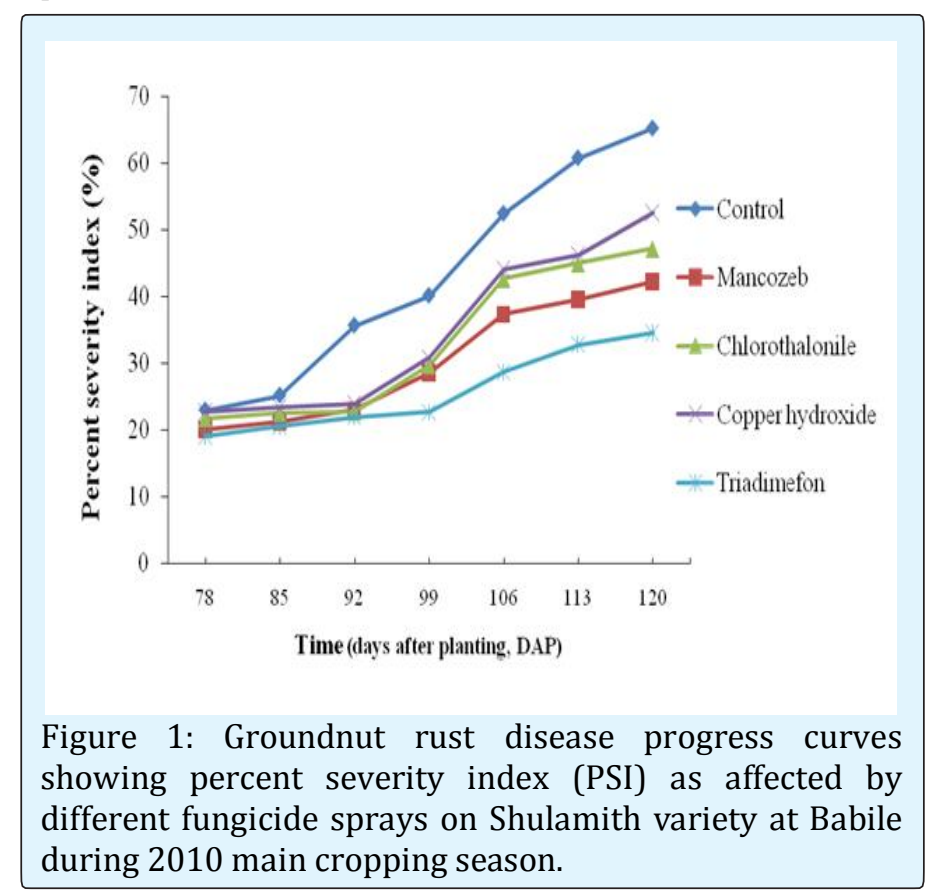




\section{Open Access Journal of Agricultural Research}

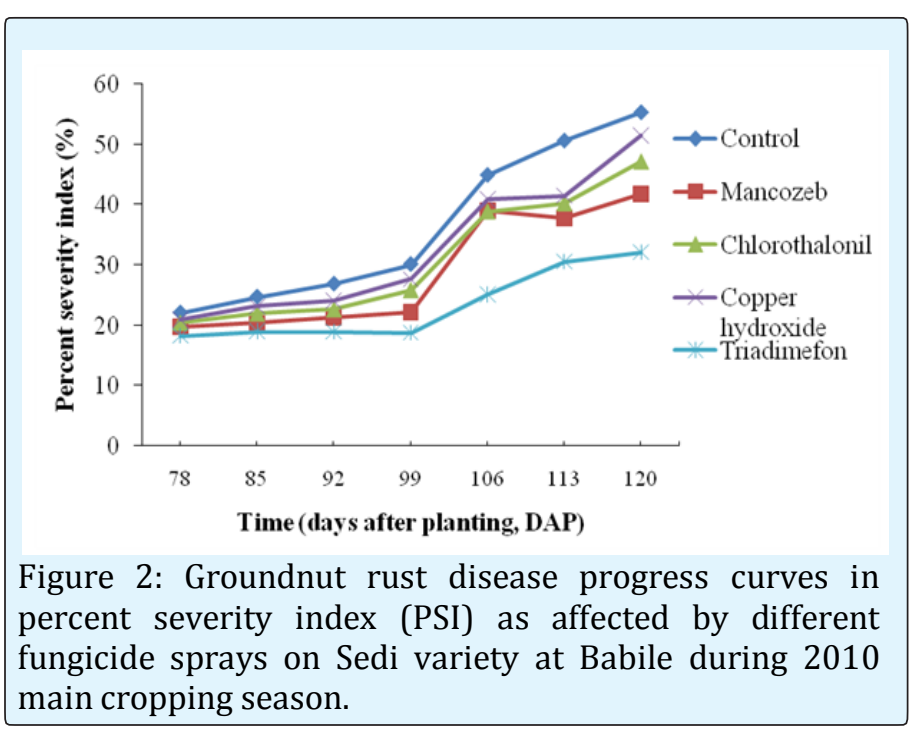

Area under disease progress curve (AUDPC): Highly significant $(p<0.001)$ differences were observed in the magnitude of AUDPC among different foliar spray fungicides. The highest (353.37\%days) AUDPC was obtained from the control (unsprayed plots) of the two groundnut varieties. This AUDPC value was significantly different from all the other fungicide treatments (Table 1), whereas the lowest AUDPC values (257.37\% days and $243.37 \%$ days) were obtained on plots treated with triadimefon fungicides on Shulamith and Sedi varieties respectively (Table 1).

The variety Shulamith treated with the fungicides triadimefon, mancozeb, chlorothalonil and copper hydroxide had AUDPC values of $257.37 \%$-days, $268.85 \%$ days, 306.44\%-days and 312.29\%-days, respectively (Table 1). The variety Sedi treated with the fungicides triadimefon, mancozeb, chlorothalonil and copper hydroxide had AUDPC values of $243.37 \%$-days, $268.78 \%$ days, $277.06 \%$-days and $288.33 \%$-days, respectively (Table 1). Moreover, interaction effect of varieties $\mathrm{x}$ fungicides was significantly $(p<0.001)$ different in reducing AUDPC. The high degree of significant difference in AUDPC-values among the fungicide treatments indicated that fungicides had varying impacts on groundnut rust development. There were similar previous reports that triadimefon acted against infections and controlled the secondary spread of the disease, reducing the disease development [20].

\begin{tabular}{|c|c|c|c|}
\hline $\begin{array}{c}\text { Groundnut } \\
\text { Variety }\end{array}$ & Chemical & AUDPC $^{\mathbf{1}}$ & DPR $^{\mathbf{2}}$ \\
\hline Shulamith & Chlorothalonil & $306.44^{\mathrm{b}}$ & $0.025^{\mathrm{bc}}$ \\
\hline & $\begin{array}{c}\text { Copper } \\
\text { hydroxide }\end{array}$ & $312.29^{\mathrm{b}}$ & $0.027^{\mathrm{b}}$ \\
\hline & Mancozeb & $268.85^{\mathrm{de}}$ & $0.014^{\mathrm{de}}$ \\
\hline & Triadimefon & $257.37^{\mathrm{ef}}$ & $0.004^{\mathrm{f}}$ \\
\hline & Control & $353.37^{\mathrm{a}}$ & $0.033^{\mathrm{a}}$ \\
\hline & Chlorothalonil & $277.06^{\mathrm{de}}$ & $0.016^{\mathrm{de}}$ \\
\hline & $\begin{array}{c}\text { Copper } \\
\text { hydroxide }\end{array}$ & $288.33^{\mathrm{cd}}$ & $0.020^{\text {cd }}$ \\
\hline & Mancozeb & $268.78^{\mathrm{de}}$ & $0.012^{\mathrm{e}}$ \\
\hline & Triadimefon & $243.37^{\mathrm{f}}$ & $0.002^{\mathrm{f}}$ \\
\hline CSD $(0.05)$ & Control & $324.08^{\mathrm{b}}$ & $0.027^{\mathrm{b}}$ \\
\hline CV (\%) & & 23.26 & 0.005 \\
\hline
\end{tabular}

Table 1: Mean levels of AUDPC and disease progress rates of groundnut rust following different fungicide treatments at Babile in 2010 main cropping season.

Values followed by the same letter within a column do not differ significantly according to Tukey's honestly significant difference test at $\mathrm{p} \leq 0.05$

${ }^{1}$ AUDPC $=$ Area under Disease Progress Curve, 2DPR = Disease progress rate,

Disease progress rate: Groundnut rust increased by 0.033 and 0.027 units each day on unsprayed plots of Shulamith and Sedi varieties, respectively (Table 1). This rate ( 0.033 unit per day) was reduced by four and three times on Shulamith plots sprayed with triadimefon and mancozeb, respectively (Table 1). On the other hand, the rust disease progress rate (0.027 unit per day) was reduced by four and two times on Sedi plots sprayed with triadimefon and mancozeb, respectively (Table 1). The overall mean disease progress rates of all the plots sprayed with different fungicides compared with unsprayed plots (control) were significantly $(p<0.001)$ different. Shulamith sprayed with triadimefon gave the lowest (0.004 unit per day) disease progress rate, while the untreated Shulamith (control) yielded the highest (0.033 unit per day) disease progress rate (Table 1 ).

Generally relatively lower disease progress rates were observed on plots treated with different fungicides than on untreated control plots and indicated that fungicide treatments were more effective in slowing down the disease progress rates than the rates on untreated plots. 


\section{Open Access Journal of Agricultural Research}

Shanner and Finney (1977) [15] have pointed out the value of the disease progress rate in predicting the effect of various disease control practices. The results of the present study showed that disease progress rates were lower in plots sprayed with triadimefon fungicide at 15day interval in both varieties (Shulamith and Sedi) than in plots treated with other foliar spray fungicides.

\section{Yield and yield components}

Seed yield: Significant $(p<0.001)$ variation was recorded on the seed yields obtained from plots that received different fungicide treatments (Table 2). Interaction of main effects (varieties vs. fungicides) was significantly ( $p$ $<0.001$ ) different in seed yield (Table 2). The varieties Shulamith and Sedi plots sprayed with triadimefon gave high seed yield of $1644.44 \mathrm{~kg}^{-\mathrm{ha}^{-1}}$ and 887.41-ha-1, respectively (Table 2). On the other hand, the unsprayed plots of Shulamith and Sedi gave low yield of $1014.60 \mathrm{~kg}$ ha $^{-1}$ and 748.53 kg-ha- $^{-1}$, respectively (Table 2). On both varieties, the second highest yield $\left(1543.94 \mathrm{~kg}^{-} \mathrm{ha}^{-1}\right.$ and $855.78 \mathrm{~kg}^{-h^{-1}}$ was obtained from plots sprayed with mancozeb and the lowest yield $\left(1014.60 \mathrm{~kg}^{-h} \mathrm{a}^{-1}\right.$ and $748.52 \mathrm{~kg}^{-h^{-1}}{ }^{-1}$ next to the control plots was obtained from plots sprayed with copper hydroxide (Table 2).

Different investigations have been carried out on other possible beneficial effects of triadimefon. Scheinpflug and Kuck (1987) [21] reported that wheat, peas and soybeans treated with triadimefon reduced transpiration, prevented wilting in water-stressed plants and increased yield. Similarly, soybeans exhibited high resistance to ozone, and cabbage and barley seedlings showed increased resistance to chilling with root application of triadimefon [22]. According to Scheinpflug and Kuck (1987) [21], like most other sterol biosynthesis inhibitor (SBI) fungicides, triadimefon caused stronger plant growth regulatory side benefits on dicotyledonous plants, such as groundnut than on monocotyledonous plants. It is thus very unlikely that possible yield enhancing effects of triadimefon occurred in groundnut to explain the disparity in the effects of treatments on yield and on disease severity.

Yield components: Stand count at harvest, number of pods per plant, number of seeds per pod, shelling percentage and hundred seed weight were highly and significantly different $(\mathrm{p}<0.001)$ between varieties (Table 2). Moreover, significant $(\mathrm{p}<0.001)$ variation was obtained among different foliar spray fungicides in all yield components (Table 2). Plots of Shulamith and Sedi varieties sprayed with triadimefon had higher stand count at harvest, number of pods per plant and hundred seed weight than unsprayed plots (control) (Table 2). Shulamith plots sprayed with triadimefon had higher (58.16 g) hundred seed weights than the unsprayed plots (42.63 g) (Table 2). But, on Shulamith variety, the hundred seed weight obtained from chlorothalonilsprayed plots was significantly $(\mathrm{p}<0.001)$ different from that of plots sprayed with copper hydroxide (Table 2). Besides, the number of pods per plant obtained from copper hydroxide sprayed Shulamith plots was not significantly different from the unsprayed plots (control).Compared to the contact fungicide sprayed plots, the systemic fungicide (triadimefon) gave higher seed yield and yield components when it was sprayed at 15 days interval. In general, for all management strategies adult plant resistant reaction reduces the efficiency of the pathogen during the reproductive growth stages of the host thus it may avoid the need for late-season fungicide application [23]. Generally experiments on fungicidal control of rust have been conducted in many countries in the semi-arid tropics and largely increased seed yield and pods per plant have been obtained [24]

\begin{tabular}{|c|c|c|c|c|c|c|c|c|}
\hline \multirow[b]{2}{*}{ Variety } & \multirow{2}{*}{ Chemicals } & \multicolumn{7}{|c|}{ Yield and Yield Components } \\
\hline & & YPH (kg-ha-1)1 & RYL (\%) ${ }^{2}$ & HSW $(g)^{3}$ & PPP4 & SPP5 & $\mathrm{SCH}^{6}$ & SP $(\%)^{7}$ \\
\hline \multirow{5}{*}{ Shulamith } & Chlorothalonil & $1354.87 \mathrm{c}$ & $28.47 \mathrm{bc}$ & $49.80^{\mathrm{cd}}$ & $17.71^{\mathrm{c}}$ & $1.87^{b}$ & $32^{\mathrm{cd}}$ & $68.33^{b c}$ \\
\hline & Copper hydroxide & $1255.23^{\mathrm{d}}$ & $30.78^{\mathrm{b}}$ & $48.36^{\mathrm{de}}$ & $16.35^{\mathrm{d}}$ & $1.83^{b}$ & $31^{\text {cd }}$ & $64.96^{\mathrm{de}}$ \\
\hline & Mancozeb & $1543.94 \mathrm{~b}$ & $21.47^{\mathrm{d}}$ & $54.43^{\mathrm{b}}$ & $19.64^{b}$ & $1.85^{b}$ & $37 \mathrm{bc}$ & $69.74 \mathrm{~b}$ \\
\hline & Triadimefon & $1644.44^{\mathrm{a}}$ & $0.00^{\mathrm{f}}$ & $58.16^{\mathrm{a}}$ & $24.64^{\mathrm{a}}$ & $1.84^{\mathrm{b}}$ & $43^{\mathrm{ab}}$ & $80.68^{a}$ \\
\hline & Control & $1014.60^{\mathrm{e}}$ & $35.55^{\mathrm{a}}$ & $42.63^{\mathrm{fg}}$ & $16.35^{\mathrm{d}}$ & $1.84^{\mathrm{b}}$ & $29 \mathrm{~d}$ & $62.40^{\mathrm{ef}}$ \\
\hline \multirow[t]{3}{*}{ Sedi } & Chlorothalonil & $797.50^{\mathrm{h}}$ & $21.15^{\mathrm{d}}$ & 40.50 gh & $12.73^{\mathrm{f}}$ & $2.22^{\mathrm{a}}$ & $43^{\mathrm{ab}}$ & $61.90 \mathrm{fg}$ \\
\hline & Copper hydroxide & $777.06^{\mathrm{i}}$ & $25.03^{\mathrm{cd}}$ & $38.13^{\mathrm{hi}}$ & $10.33^{\mathrm{g}}$ & $2.41^{\mathrm{a}}$ & $43^{\mathrm{ab}}$ & $59.24 \mathrm{~g}$ \\
\hline & Mancozeb & $855.78^{g}$ & $7.64^{\mathrm{e}}$ & $45.43^{\text {ef }}$ & $14.22^{\mathrm{e}}$ & $1.86^{\mathrm{a}}$ & $47^{a}$ & $66.47^{\mathrm{cd}}$ \\
\hline
\end{tabular}

Alehegn $M$ et al. Groundnut Rust (Puccinia arachidis) Management through Integration of Host Resistance with Fungicides at Babile, Eastern Ethiopia. 


\section{Open Access Journal of Agricultural Research}

\begin{tabular}{|c|c|c|c|c|c|c|c|c|}
\hline & Triadimefon & $887.41^{\mathrm{f}}$ & $0.00^{\mathrm{f}}$ & $51.93^{\mathrm{bc}}$ & $15.60^{\mathrm{d}}$ & $2.36^{\mathrm{a}}$ & $48^{\mathrm{a}}$ & $69.20^{\mathrm{bc}}$ \\
\hline & Control & $748.52^{\mathrm{j}}$ & $35.46^{\mathrm{a}}$ & $37.03^{\mathrm{i}}$ & $10.02^{\mathrm{g}}$ & $2.25^{\mathrm{a}}$ & $44^{\mathrm{a}}$ & $55.15^{\mathrm{h}}$ \\
\hline & LSD $(0.05)$ & 5.64 & 4.38 & 2.99 & 1.22 & 0.29 & 7.09 & 3.03 \\
\hline & CV $(\%)$ & 0.3 & 12.33 & 3.73 & 4.54 & 8.44 & 10.35 & 2.69 \\
\hline
\end{tabular}

Table 2: Yield per hectare, relative yield loss, hundred seed weight, pods per plant, seeds per pod, stand count at harvest and shelling percentage, mean loss due to groundnut rust with different levels of fungicides treatments at Babile during 2010 main cropping.

Values followed by the same letter within a column do not differ significantly according to Tukey's honestly significant difference test $(\mathrm{p} \leq 0.05)$.

${ }^{1}$ yield per hectare ${ }^{3}$ hundred seed weight

${ }^{5}$ seeds per pod $\quad{ }^{7}$ shelling percentage

${ }^{2}$ relative yield loss $\quad{ }^{4}$ pods per plant

${ }^{6}$ stand count at harvest

\section{Relative yield loss}

The highest seed yield (1644.44 kg-ha-1) of Shulamith and $887.40 \mathrm{~kg}$-ha- 1 of Sedi were obtained when the varieties were sprayed with triadimefon. The yield loss that was incurred by using one of the fungicide sprays was calculated relative to the yield of maximum protected plots and it varied among the different fungicides on the control (Table 2). Higher yield loss (35.55\%) occurred on Shulamith unsprayed (control) plots (Table 2). Similarly, higher yield loss $(35.46 \%)$ occurred on Sedi unsprayed (control) plots (Table 2). The second highest yield loss $(25.03 \%$ and $30.78 \%)$ was obtained from plots sprayed with copper hydroxide fungicide in Sedi and Shulamith varieties, respectively (Table 2). However, on Shulamith and Sedi the second least yield loss $(21.47 \%$ and $7.64 \%)$ occurred on mancozeb treated plots, respectively (Table 2). Furthermore, the third yield loss of $28.47 \%$ and 21.15\% occurred when Shulamith and Sedi plots, respectively, were sprayed with chlorothalonil (Table 2). This would mean that in cases when triadimefon is not available mancozeb could be the second choice.

The result indicated that using resistance varieties and applying fungicides on susceptible varieties before disease onset is important to minimize the effect of disease on groundnut production. A similar other research has showed that the reduction in pod yield due to occurrence of foliar diseases is attributed mainly to leaf loss and reduced leaf area index due to defoliation $[25,26]$. There is a minor additional component of yield loss that is attributed to the effect of necrotic spots on photosynthesis. Yield losses were estimated by applying selective fungicides on a wide range of susceptible and resistant varieties and losses were found to be less in the resistant than in the susceptible varieties [27].

\section{Association of disease parameters and yield of groundnut}

Correlation analysis of yield with severity, AUDPC and disease progress rate revealed the existence of significant relationships among the different parameters (Table 3). Percent severity index (PSI) was negatively $(\mathrm{r}=-0.91)$ correlated to yield that indicated high negative effect of rust on groundnut yield (Table 3). AUDPC and disease progress rate were also negatively $(r=-0.85$ and -0.64$)$ correlated, respectively, with yield (Table 3), while, percent severity index and AUDPC were more significantly and positively $(r=0.92)$ correlated. Similarly, percent severity index was positively $(r=0.71)$ correlated with disease progress rate (Table 3). On the other hand, the correlations observed among disease parameters (severities, AUDPCs and disease progress rates) were all positive. The investigation indicated that when PSI increased, the others (area under disease progress curve and disease progress rate) also steadily increased, while the disease progress rate was expected to slow down after the disease reached highest severity levels. It is a well-established fact that the availability of healthy plant tissue for infection limits the further development of epidemics; as epidemics progresses less plant tissue will be available for further infection and the rate of epidemic development [28].

\begin{tabular}{|c|c|c|c|c|}
\hline & $\begin{array}{c}\text { YPH(kg-ha- } \\
\mathbf{1}^{\mathbf{2}}\end{array}$ & PSI $^{\mathbf{3}}$ & AUDPC $^{\mathbf{4}}$ & DPR $^{\mathbf{5}}$ \\
\hline YPH(kg-ha-1) & -------- & & & \\
\hline PSI & $-0.91^{* *}$ & -------- & & \\
\hline AUDPC & $-0.85^{* *}$ & $0.92^{* *}$ & ------- & \\
\hline DPR & $-0.64^{*}$ & $0.71^{*}$ & $0.73^{* *}$ & -------- \\
\hline
\end{tabular}

Table 3: Correlation coefficients (r) between seed yield and disease parameters at final disease assessment $(120$ $\mathrm{DAP}^{1}$ ) of groundnut treated with different fungicides on natural infections at Babile during 2010 cropping season.

${ }^{1}$ Days after planting ${ }^{*}=$ significant $(\mathrm{p} \leq 0.05),{ }^{* *}=$ highly significant $(\mathrm{p} \leq 0.01), * * *=$ very highly significant $(\mathrm{p}$ $\leq 0.001)$. 


\section{Open Access Journal of Agricultural Research}

${ }^{2}$ Yield per hectare, ${ }^{3}$ percent severity index, ${ }^{4}$ Areas under disease progress curve and ${ }^{5}$ Disease progress rate.

\section{Summary and Conclusions}

Groundnut is one of the four economically important cultivated oilseed crops, including noug, flax and sesame in Ethiopia. It is largely produced in the eastern part of the country. The importance of groundnut appears to arise from its adaptability to extremely wider environments in areas like arid and semi- arid tropics and its high productivity. Groundnut yields are, however, reduced due to many abiotic and biotic factors of which leaf diseases mainly (leaf spot and rust) are economically important problems. Leaf rust of groundnut, which is caused by Puccinia arachidis, is the most common and economically important foliar disease of the crop. However, in Ethiopia no more research efforts have been directed to develop suitable methods for its management. In this study four fungicides viz. chlorothalonil, copper hydroxide, mancozeb and triadimefon, were evaluated for their efficiency using two moderately resistant and susceptible varieties in RCBD design in a factorial arrangement with three replications under natural field infection Haramaya University Sub- Research Station in Babile. Based on the findings of this study, it can be concluded that groundnut rust is an important disease that calls for due attention in the study area for effective and efficient management with fungicides and resistant varieties. Thus, three times foliar sprays with triadimefon at a rate of 0.5 a.i. $\mathrm{kg}^{-h^{-1}}$ starting right after the appearance of the rust at 15-day interval could manage the disease better than the rest of the fungicides. As a final point, we recommend that suitable fungicides should be applied as soon as the first rust pustule is noticed and further studies should be conducted to workout effective and economical management options for the rust disease under different ecological situations and thereby to enhance high quality groundnut production in Ethiopia.

\section{Acknowledgement}

We wish to thank Mr. Maseresha and his colleagues for their technical assistance during field work. The financial and material support from Ministry of Education and Haramaya University is gratefully acknowledged.

\section{References}

1. FAO (Food and Agriculture Organization) (2007) Food and Agriculture Organization of the United Nations, FAO Statistical Database.
2. Getnet A, Nigussie A (1992) Production and research on oilseeds in Ethiopia. In: Proceedings of the First National Oilseeds Workshop in Ethiopia, 3-5 December 1991. Addis Ababa: Institute of Agricultural Research 312.

3. FAO (Food and Agriculture Organization) (2004). Worldwide regulation for mycotoxins in food and feed in 2003.

4. Sastri BN (1988) The wealth of India. A dictionary of raw materials and industrial importance of groundnut.

5. Adugna W (1992) Groundnut breeding in Ethiopia: 312. In: Proceedings of the First National Oilseeds Workshop in Ethiopia, 3-5 December 1991. Addis Ababa: Institute of Agricultural Research.

6. Geremew T, Asfaw T (1992) Groundnut and sesame diseases in Ethiopia. In: Proceedings of the First National Oilseeds Workshop in Ethiopia, 3-5 December 1991. Addis Ababa: Institute of Agricultural Research 312.

7. Getenet T, Sakhuja PK, Swart WJ, Tana T (2007) Integrated management of groundnut root rot using seed quality and fungicide seed treatments. Int J Pest Management 53(1): 53-57.

8. Subrahmanyam P, Mehan VK, Nevilland DJ, McDonald D (1980) Research on fungal diseases of groundnut at ICRISAT. In: Proceedings of the International Workshop on Groundnut, 13-17 October 1980. ICRISAT Center, India 193-198.

9. Cole DI (1987) Rust disease of groundnut in southern Africa: Present situation and possible interactions with other groundnut foliar diseases.In: Cooperative Extension Service/Institute of Food and Agricultural Sciences/ University of Cooperative Extension System Pp 109-114.

10. Weiss EA (2000) Oilseed Crops. London: Blackwell Science.

11. Mayee CD (1983) Groundnut rust review. Indian Botanical Report 75: 85.

12. Abdi A (2004) The effect of plant density and variety on yield and yield components of groundnut at Babile, Eastern Ethiopia, MSc thesis. Alemaya University, Alemaya, Ethiopia 58. 


\section{Open Access Journal of Agricultural Research}

13. Subrahmanyam P, McDonald D, Walliyer F, Reddy LJ, Nigam SN, et al. (1995) Screening methods and sources of resistance to rust and leaf spot of groundnut. Information Bulletin No. 47, Patancheru. 502324, Andhara Pradesh, India, ICRISAT 24.

14. Wheeler JB (1969) An introduction to plant diseases. John Wiley and Sons Ltd., London.

15. Shanner G, Finney R (1977) Inheritance of slowmildewing resistance in wheat. In: Proceedings of the American Phytopathology Society 49-52.

16. Robert GD, James HT (1991) A Biometrical Approach Principles of Statistics. (2nded.) New York, USA.

17. Van der Plank JE (1963) Plant disease epidemics and control. Academic Press, New York 344.

18. Campbell CL (1998) Disease progress in time: Modelling and data analysis. In; DG Jones (Ed.) The Epidemiology of Plant Diseases. Kluwer Academic Publishers Dordrecht. The Netherlands. pp 181-204.

19. Singh SJ, Soki SS, Grewal RK (1981) Relative efficiency of fungi toxicants against peanut rust. Indian Phytopathology 34: 272-275.

20. Kapoor AS, Sugha SK (1995) Efficacy of different fungicides in controlling powdery mildew (Erysiphepisi) of pea (Pisumsativum) in field. Indian Journal of Science 65: 771-773.

21. Scheinpflug H, Kuck KH (1987) Stereol biosynthesis inhibiting piperazine, pyridine, pyrimidine and azole fungicides. In: Lyr $\mathrm{H}$ (eds) Modern Selective Fungicides VEB 173-204.
22. Fletcher RA, Hofstra G (1985) Triadimefon: a plant multi-protectant. Plant and Cell Physiology 26(4): 775-780.

23. Headrick JM, Pataky JK (1987) Expression of partial resistance to common rust in sweet corn hybrids at various host growth stages. Phytopathology 77: 454458.

24. Litterll RH, Smith DH (1980) Management of peanut foliar diseases with fungicides. Plant Disease 64(4): 356-361.

25. Subramanyam P, Wongkaew S, Reddy DV, Demski JW, McDonald D, et al. (1992) Field diagnosis of groundnut diseases information bulletin, Patancheru, Andhra Pradesh, India: ICRISAT.

26. Nutter FW, Littrell RH (1996) Relationship between defoliation, canopy reflectance and pod yield in peanut late leaf spot pathosystems. Crop Protection 15(2): 135-142.

27. Subrahmanyam P, Williams JH, McDonald D, Gibbons RW (1984) The influence of foliar diseases and their control by selective fungicides on a range of groundnut (Arachishypogaea L.) genotypes. Annals of Applied Biology 104(3): 467-476.

28. Freedman J, Mackenzie DR (1992) Disease progress curves, their mathematical description and analysis to formulate predictors for loss equations. In: Teng PS (eds) Crop Loss Assessment and Pest Management. International Book Distributing Co. Lucknow, India 37-48. 